\title{
Fasilitas Pemenuhan Kebutuhan Air Bersih untuk Masyarakat Penjaringan
}

\author{
Bernadeth Shirley ${ }^{1)}$, Suwandi Supatra ${ }^{2)}$ \\ 1)Program Studi S1 Arsitektur, Fakultas Teknik, Universitas Tarumanagara, bernadethshirley297@gmail.com \\ 2) Program Studi S1 Arsitektur, Fakultas Teknik, Universitas Tarumanagara, suwandis@dtt.untar.ac.id
}

\begin{abstract}
Abstrak
Wilayah Penjaringan, Jakarta Utara merupakan wilayah yang tidak memiliki akses sumber air bersih yang handal. Kelurahan yang merupakan wilayah terpadat dan dengan tingkat kemiskinan yang tinggi di Jakarta Utara tersebut tidak memiliki sumber air pada umumnya yaitu air sumur dan PAM. Dikarenakan kondisi air di dalam tanah yang asin, tercemar, dan lemah (Kelurahan Penjaringan merupakan wilayah dengan penurunan permukaan tanah lebih dari $80 \mathrm{~cm}$ dalam kurun waktu sepuluh tahun), masyarakat bergantung pada air bersih yang dapat dibeli eceran yang tergolong mahal (Rp. 600.000,- per bulan) dan air bersih bantuan pemerintah yang sangat terbatas kuantitasnya. Bila tidak dapat memperoleh air bersih dari kedua sumber tersebut, maka masyarakat menggunakan air yang tercemar (baik air tanah maupun air dari sumber alternatif seperti waduk) yang kemudian berakibat pada penurunan kondisi fisik. Tentu, penggunaan air Waduk Pluit memiliki potensi untuk menjadi solusi krisis air bersih Penjaringan, tetapi setelah melalui proses penjernihan. Memiliki kemampuan memproses air Waduk Pluit yang kotor dan tercemar menjadi air bersih dan layak minum, riset dan penelitian untuk mengembangkan kualitas air bersih, memberikan edukasi dan pengenalan tentang sistem penjernihan air dan perawatannya, dan tentunya tempat masyarakat Penjaringan dapat memperoleh air bersih yang dapat digunakan untuk kebutuhan sehari-hari dan konsumsi, merupakan tujuan perancangan Fasilitas Pemenuhan Kebutuhan Air Bersih untuk Masyarakat Penjaringan.
\end{abstract}

Kata kunci: penjernihan air; fasilitas riset; krisis air.

\begin{abstract}
Penjaringan, North Jakarta is an area that does not have access to a reliable source of clean water. The area, the most densely populated area and with a high poverty rate in North Jakarta, does not have access to the widely used water sources, namely well water and PAM. Due to the weak soil (Penjaringan Village is an area with a land subsidence of more than 80 $\mathrm{cm}$ in a period of ten years) and salty and polluted water, the community depends on water they can acquire at retail for a rather expensive price (Rp. 600,000, - per day) and the water provided by the government which is very limited in quantity. For people who couldn't get water from these two sources, they would use polluted water (both ground water and water from alternative sources such as reservoirs) which then results in the number of sick people rising. Of course, the use of Pluit Reservoir water has the potential to be a solution to the Penjaringan clean water crisis, but after going through a purification process. Having the ability to process dirty and polluted Pluit Reservoir water into clean and potable water, research to improve clean water quality, provide education and introductions about water purification systems and their treatments, and of course a provide clean and potable water for the daily needs and consumption for people of Penjaringan, is the purpose of Fasilitas Pemenuhan Kebutuhan Air Bersih untuk Penjaringan.
\end{abstract}

Keywords: research center; water crisis; water treatment.

\section{PENDAHULUAN}

Proyek Perancangan mewujudkan pemanfaatan air Waduk Pluit yang telah dijernihkan untuk memperbaiki kualitas dan kuantitas air bersih Kelurahan Penjaringan. Fasilitas terdiri atas sistem penjernihan air yang dilengkapi dengan kemampuan riset dan observasi serta edukasi. Dengan 
bertambahnya sumber air bersih dan adanya pengetahuan mengenai proses penjernihan air yang sederhana ataupun dengan alat tertentu, maka peluang masyarakat yang dapat secara mandiri memperoleh air bersih dirumah tangga mereka akan semakin tinggi sedangkan persentase rumah tangga yang perolehan air bersihnya sangat kecil akan semakin rendah. Tujuan proyek perancangan fasilitas ini dapat dinyatakan terwujud apabila terdapat peningkatan kualitas hidup masyarakat Penjaringan setelah adanya perbaikan kualitas dan kuantitas air bersih yang dapat diperoleh masyarakat.

This Project realizes the utilization of the purified water from Pluit Reservoir to improve the quality and quantity of clean water in Penjaringan. The facility consists of a water purification system equipped with capability to do research, observation, and education. With the improvement of quality and quantity of clean water and acquirement of knowledge about simple water purification processes or with certain tools, the chances of people who can independently obtain clean water in their households will increase while the percentage of households using polluted water for daily needs will decrease. The purpose of this facility design project will be realized with the improvement in the quality of life of the people of Penjaringan after the improvement to the quality and quantity of the obtained water.

\section{Latar Belakang}

Masyarakat Penjaringan tidak memiliki sumber air bersih yang handal baik untuk konsumsi dan untuk kebutuhan sehari hari. Masyarakat Kelurahan Penjaringan yang merupakan kelurahan dengan tingkat kemiskinan tertinggi dan kondisi tanah yang terparah di Jakarta Utara memperoleh air bersih yang dibeli secara eceran yang mahal dan/atau dari bantuan pemerintah yang terbatas. Terdapat sejumlah masyarakat yang tidak dapat memperoleh air bersih dengan kedua cara tersebut dan menggunakan air Waduk Pluit yang tercemar untuk mencuci. Walaupun Waduk Pluit memiliki potensi menjadi sumber air yang handal, air tidak dapat langsung dipergunakan dan harus melalui proses penjernihan terlebih dahulu.

Urgensi Isu: Tinggi

\section{Rumusan Masalah}

Air bersih merupakan kebutuhan vital setiap makhluk hidup. Untuk kebutuhan sehari-hari, penggunaan air bersih dapat mencapai 300 liter per orang per hari sedangkan populasi Kelurahan Penjaringan yaitu 128.582 jiwa (sumber: BPS). Selain itu, jumlah penduduk terus bertambah setiap tahunnya, mempengaruhi peningkatan kebutuhan air bersih and kepadatan kelurahan tersebut. Penggunaan air Waduk Pluit untuk kebutuhan sehari-hari sejumlah masyarakat sebaiknya dilakukan apabila air waduk tersebut dinyatakan layak penggunaan dan tidak terlalu tercemar.

Batasan Masalah : Kebutuhan air bersih masyarakat Penjaringan belum terpenuhi.

Tujuan Desain : Meningkatkan kualitas dan kuantitas air bersih untuk konsumsi dan kebutuhan sehari-hari masyarakat Kelurahan Penjaringan.

\section{KAJIAN LITERATUR}

Metode Pengolahan Air Baku (sumber: Afrina, Poppy. (n.d). Air Baku)

Sumber air baku memegang peranan yang sangat penting dalam industri air minum. Air baku atau Raw Water merupakan awal dari suatu proses dalam penyediaan dan pengolahan air bersih. Berdasarkan SNI 6773:2008 tentang Spesifikasi Unit Paket Instalasi Pengolahan Air dan SNI 6774:2008 tentang Tata Cara Perencanaan Unit Paket Instalasi Pengolahan Air pada bagian Istilah dan Definisi yang disebut dengan Air Baku adalah : "Air yang berasal dari sumber air pemukaan, cekungan air tanah dan atau air hujan yang memenuhi ketentuan baku mutu tertentu sebagai air baku untuk air minum" Sumber air baku bisa berasal dari sungai, danau, sumur air dalam, mata air dan bisa juga dibuat dengan caramembendung air buangan atau air laut. 
Dalam mengatasi masalah pemenuhan kebutuhan air bersih diperlukan penerapan teknologi pengolahan air yang sesuai dengan kondisi sumber air baku, kondisi sosial budaya, ekonomi, dan SDM masyarakat setempat. Menurut Balitbang Provinsi Riau, terdapat beberapa metode tersebut yaitu :

- Metode Oksidasi

Proses menggunakan Ozon yang sering dikombinasikan dengan lampu ultraviolet atau hidrogen peroksida. Dengan melakukan kombinasi ini akan didapatkan dengan mudah hidroksil radikal dalam air yang sangat dibutuhkan dalam proses oksidasi senyawa organik. Teknologi oksidasi ini tidak hanya dapat menguraikan senyawa kimia beracun, tetapi juga dapat menghilangkannya sehingga limbah padat (sludge) dapat diminimalisasi hingga mendekati $100 \%$.

- Metode Flokulasi

Flokulasi adalah penggabungan dari partikel-partikel hasil koagulasi menjadi partikel yang lebih besar dan dapat mengendap dengan cara pengadukan lambat. Dalam hal ini proses koagulasi harus diikuti flokulasi yaitu pengumpulan koloid terkoagulasi sehingga membentuk flok yang mudah terendapkan atau transportasi partikel tidak stabil, sehingga kontak antar partikel dapat terjadi.

- Metode Adsorbsi

Adsorpsi (penyerapan) adalah suatu proses pemisahan dimana komponen dari suatu fase fluida/cairan berpindah ke permukaan zat padat yang menjerap (adsorban).

- Metode Koagulasi

Koagulasi merupakan proses pengolahan air dengan menggunakan sistem pengadukan cepat sehingga dapat mereaksikan bahan kimia (koagulan) secara seragam ke seluruh bagian air di dalam suatu reactor sehingga dapat membentuk flok-flok yang berukuran lebih besar dan dapat diendapkan diproses sedimentasi.

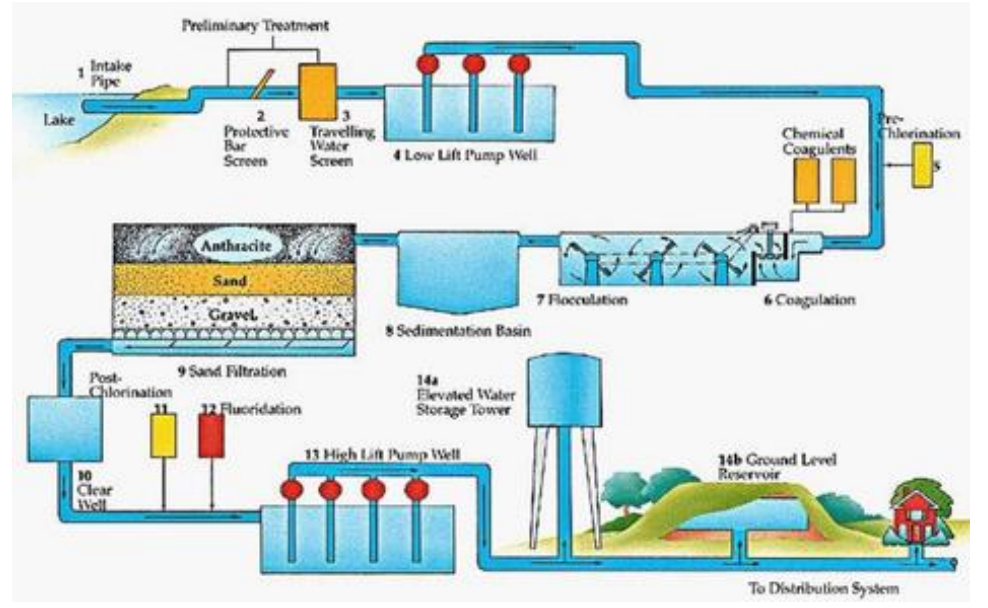

Gambar 1. Sistem Pengolahan Air Danau / Waduk

Sumber: Researchgate.net diakses pada tanggal 12 Agustus 2021

\section{Fasilitas Riset dan Laboratorium}

Menurut Watch (2000), terdapat beberapa kebutuhan utama mendorong pengembangan model desain laboratorium dan riset :

- Kebutuhan untuk menciptakan "bangunan sosial" yang mendorong interaksi dan penelitian berbasis tim

- Kebutuhan untuk mencapai keseimbangan yang tepat antara laboratorium "terbuka" dan "tertutup"

- Kebutuhan akan fleksibilitas untuk mengakomodasi perubahan

- Kebutuhan untuk merancang teknologi untuk menyediakan akses ke sistem komunikasi elektronik di seluruh gedung, yang memiliki implikasi besar pada desain laboratorium

- Kebutuhan akan kelestarian lingkungan 
- Dalam beberapa kasus, kebutuhan untuk mengembangkan taman sains untuk memfasilitasi kemitraan antara pemerintah, industri sektor swasta, dan akademisi.

\section{Aquaponics}

Akuaponik digambarkan sebagai penggabungan antara sistem budidaya akuakultur (budidaya ikan) dengan hidroponik (budidaya tanaman/sayuran tanpa media tanah). Sistem ini mengadopsi sistem ekologi pada lingkungan alamiah, dimana terdapat hubungan simbiosis mutualisme antara ikan dan tanaman.

\section{Sistem Akuaponik}

Air beserta kotoran yang berasal dari budidaya ikan disalurkan kepada tanaman karena mengandung banyak nutrisi yang dibutuhkan oleh tanaman. Tanaman akan menyerap nutrisi yang berasal dari air dan kotoran ikan tadi. Sebagai gantinya, tanaman akan memberikan oksigen kepada ikan melalui air yang sudah tersaring oleh media tanam.

Akuaponik sendiri terdiri dari dua bagian utama. Bagian-bagian utama tersebut adalah bagian akuatik (air) untuk pemeliharaan hewan air dan bagian hidroponik untuk menumbuhkan tanaman. Dalam budidaya hewan air, limbah yang menumpuk di dalam air dapat bersifat toksik bagi ikan. Limbah tersebut terdiri dari urine dan feses ikan, serta sisa pakan ikan.

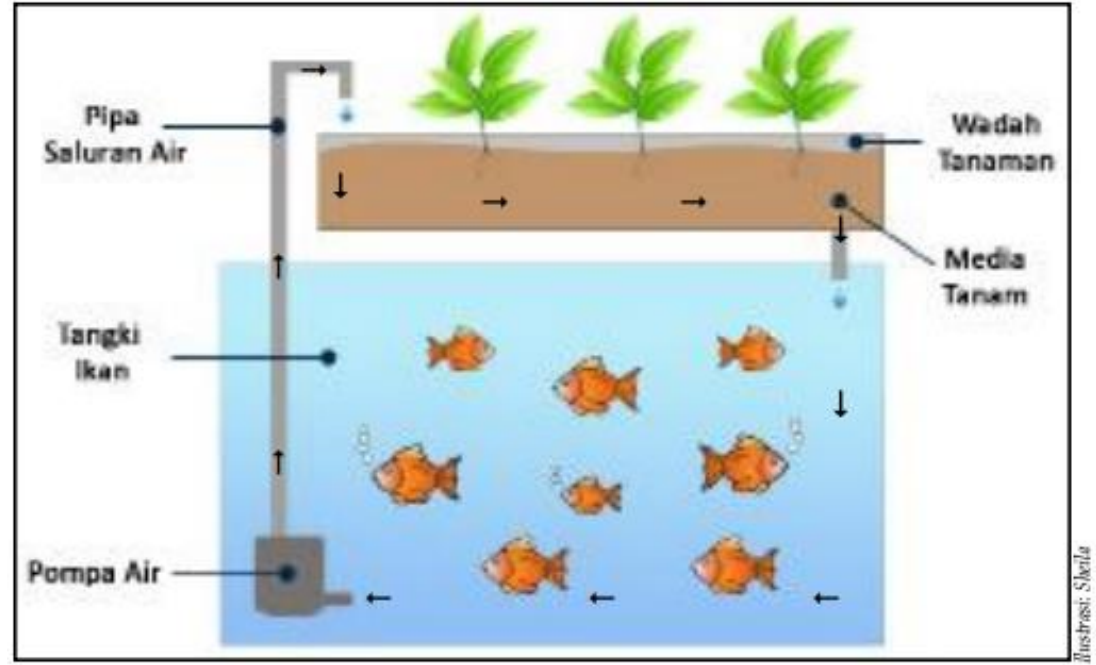

Gambar 2. Sistem Kerja Akuaponik

Sumber:http://repository.pertanian.go.id/bitstream/handle/123456789/5384/Teknologi\%20Akuaponik \%20Mendukung\%20Pengembangan

\%20UF.pdf?sequence=2 diakses tanggal 12 Agustus 2021

\section{Fasilitas Workshop}

Terdapat beberapa jenis workshop berdasarkan sifatnya menurut Rosmaryanti (2010), yaitu workshop bersifat mengikat, dan bebas atau tidak mengikat. Prosedur yang dilakukan dalam pelaksanaan workshop mencakup beberapa hal, diantaranya

- Merumuskan tujuan untuk memperoleh output/hasil akhir yang akan dicapai,

- Merumuskan pokok - pokok masalah yang akan dibahas secara rinci yang dimaksudkan untuk mempermudah proses berjalannya kegiatan, serta

- Menentukan prosedur pemecahan masalah.

Berdasarkan pada penjelasan di atas, lokakarya atau workshop adalah pertemuan orang yang bekerja sama dalam kelompok kecil dan dibatasi pada masalah yang dihadapi sendiri, pada penelitian ini terkait dengan workshop yang bersifat bebas atau tidak mengikat. Sehubung 
sasaran lokakarya/workshop yang mendasari penelitian ini adalah orang tua, maka kajian penelitian ini juga berkaitan dengan definisi serta prinsip belajar orang dewasa.

\section{METODE}

\section{Metode Pengumpulan Data}

\section{Studi Pustaka}

Penulis memilih topik krisis air bersih yang terletak di wilayah provinsi DKI Jakarta. Setelah menentukan wilayah Penjaringan yang merupakan wilayah dengan keterbatasan air bersih.

Penulis melakukan studi pustaka ekstensif pada situs-situs berita untuk mendapatkan informasi mengenai krisis air, melakukan analisa data dari situs BPS, dan melakukan riset pada kondisi air hujan dan penurunan tanah serta kasus-kasus yang memiliki kaitan dengan keterbatasan air bersih Kelurahan Penjaringan.

\section{Metode Pemilihan Lokasi Tapak dan Orientasi Massa Bangunan}

- Analisa SWOT (Strength-Weakness-Opportunity-Threat)

- Studi Banding / Comparison

- Penulis menyusun data di lokasi Kelurahan Penjaringan: populasi, mata pencaharian, pendapatan rata-rata

- Penulis menentukan tiga alternatif lokasi di Kelurahan Penjaringan yang dekat atau berada di area pemukiman penduduk dimana kebutuhan air bersih paling tinggi

- Penulis menyusun data tapak dan membuat analisa SWOT untuk ketiga lokasi yang akan dibandingkan satu dengan yang lain

- Tapak yang paling sesuai sebagai lokasi proyek perancangan yang dipilih

\section{Tahapan Penelitian / Desain}

- Bentuk gubahan massa awal ditentukan oleh proses alur aktivitas yang ada di proyek perancangan

- Dipersiapkan tiga alternatif bentuk gubahan massa dan alternatif yang paling sesuai untuk proyek perancangan yang dipilih

- Gubahan massa dikembangkan ke tahap desain arsitektural

\section{DISKUSI DAN HASIL}

\section{Lokasi Tapak}

Lokasi berada di sebelah Waduk Pluit. Berada di zona ungu. Lokasi tepat untuk merancang fasilitas dengan fungsi riset dan pengolahan air.
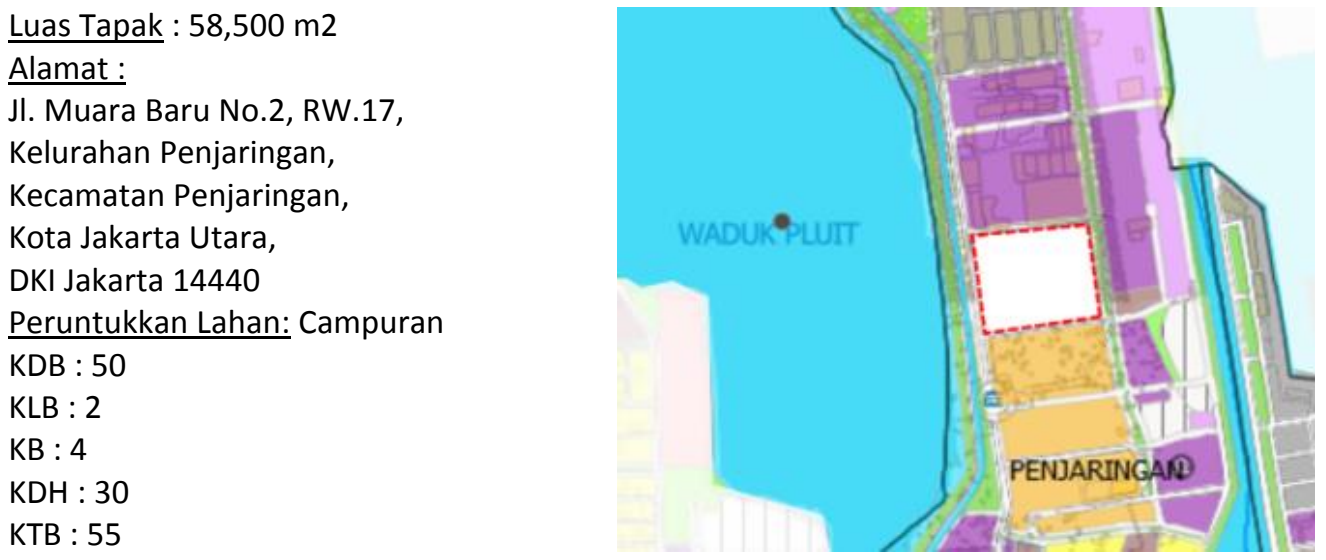

Gambar 3. Lokasi Tapak Sumber: Penulis, 2021 


\section{Konsep}

\section{Kontekstual}

Kontekstual adalah adaptasi bentuk dengan konteks, berbagai jenis konteks alam, sejarah, psiko-budaya dan buatan manusia dipertimbangkan dan penghargaan terhadap kondisi masa lalu (sebagai kondisi awal) adalah sebuah basis penghormatan terhadap tradisi yang sudah ada sebelumnya.

Konsep kontekstual terletak pada penggunaan bentuk atap pelana and letakan massa yang teratur tapi also chaotic. Lokasi proyek perancangan yang berada di area pemukiman (cluster) yang mayoritas menggunakan bentuk atap pelana dengan bangunan tampak harmonis tapi tidak sama.
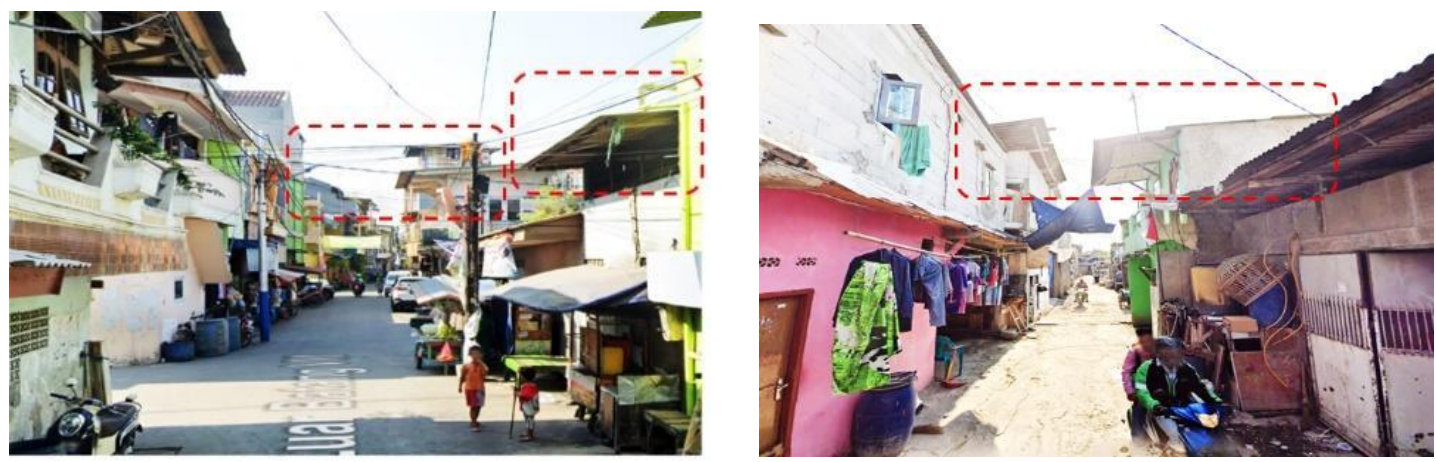

Gambar 4 dan 5. Bentuk Atap Bangunan di Area Tapak Bentuk Atap Pelana Sumber: Google Maps

\section{Keseharian}

Arsitektur keseharian adalah sebuah respon sederhana yang langsung terhubung dengan kenyataan. Arsitektur keseharian tidak membangun melalui ide-ide abstrak (ide-ide yang mengacu pada nilai estetika dan ditransfer menjadi gambar arsitektural), melainkan melihat kenyataan sebagai bahan referensi bertindak.

Konsep arsitektur keseharian terletak pada sejumlah area-area komunal. Di area pemukiman di sekitar tapak yang telah dipilih, dapat dilihat area-area dimana masyarakat dapat duduk bersantai dan bercakap-cakap.

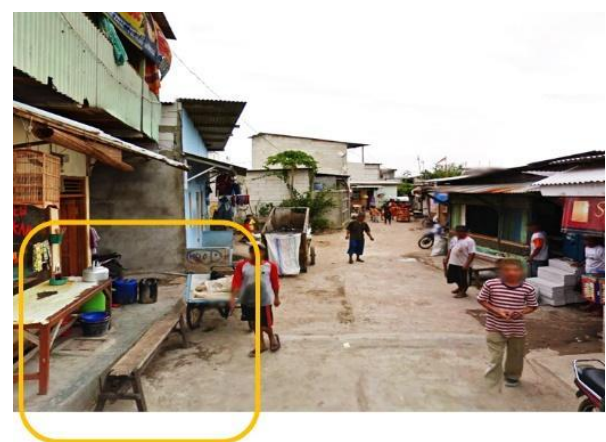

Gambar 6. Area Komunal di Depan Rumah Masyarakat Setempat Sumber: Google Maps

Konsep berdasarkan alur proses aktivitas di dalam bangunan

Zonasi berdasarkan tahapan proses aktivitas aktivitas yang didalamnya. Dimulai dari (I) Pengambilan Air Waduk Pluit, kemudian dilanjutkan ke tahap (II) yaitu Penjernihan Air Waduk Pluit (yang terbagi menjadi empat tahap: penampungan air waduk, klorinasi-koagulasi-flokasi, 
sedimentasi dan filtrasi, dan klorinasi-fluoridasi), tahap (III) yaitu penampungan air bersih, tahap (IV) yaitu riset dan pengamatan, tahap (V) yaitu akuaponik, tahap (VI) yaitu edukasi dalam bentuk fasilitas seminar dan workshop, tahap (VII) yaitu fasilitas penjualan air bersih dan bahan makanan (ikan dan sayuran). (Lihat Gambar 6)

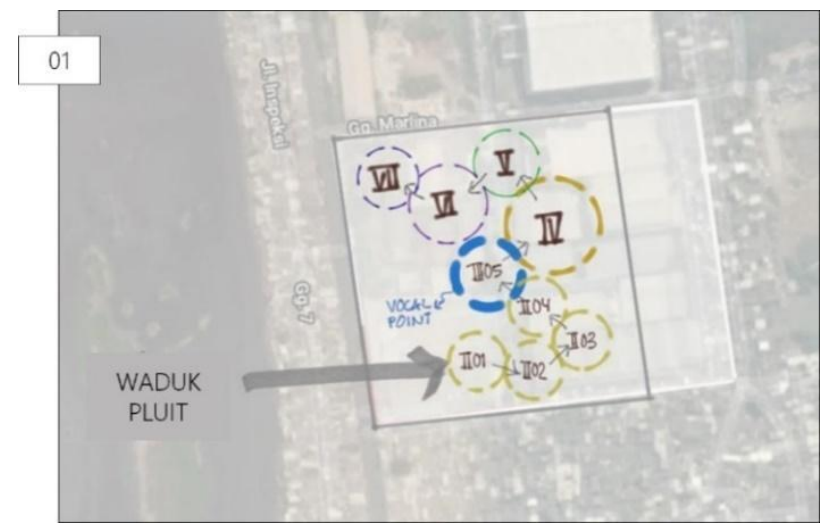

Gambar 7. Zonasi dari Alur Aktivitas Tahap 1 Sumber: Penulis, 2021

Pada tahap dua, ditengah-tengah area yang membentuk bagian utara tapak, merupakan area sirkulasi yang mengarah ke luar bangunan. (lihat Gambar 7)

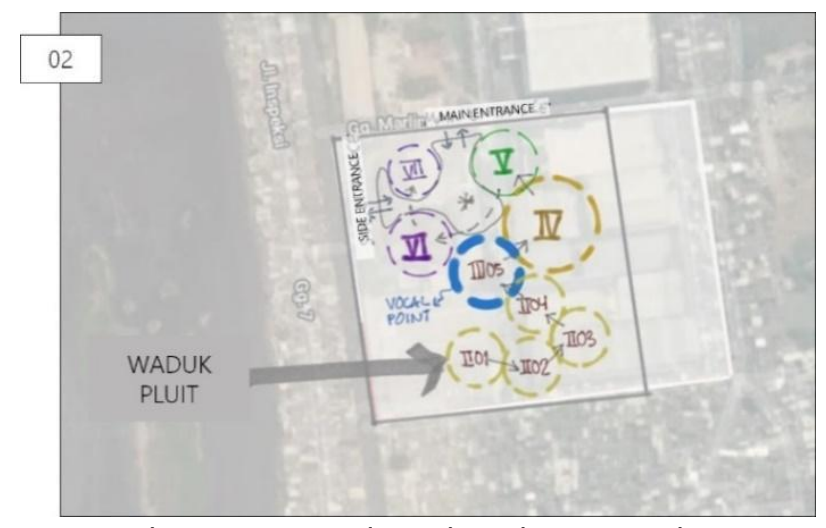

Gambar 8. Zonasi dari Alur Aktivitas Tahap 2

Sumber: Penulis, 2021

Konsep berdasarkan elevasi, second skin, dan courtyard

- $\quad$ Aksen / Vocal Point

Merupakan massa yang terletak di tengah tapak dan paling tinggi. Berfungsi sebagai tempat penampungan air bersih hasil proses penjernihan air Waduk Pluit.

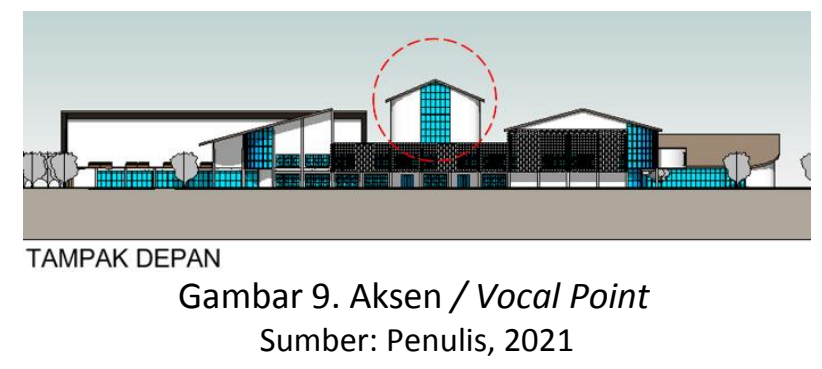

- $\quad$ Second Skin

Terdapat lapisan luar pada fasad bangunan yang berfungsi untuk mengurangi intensitas 
cahaya matahari yang masuk ke dalam bangunan, terutama di bagian laboratorium yang temperatur ruangannya terjaga. Lapisan luar bangunan tampak seperti anyaman.

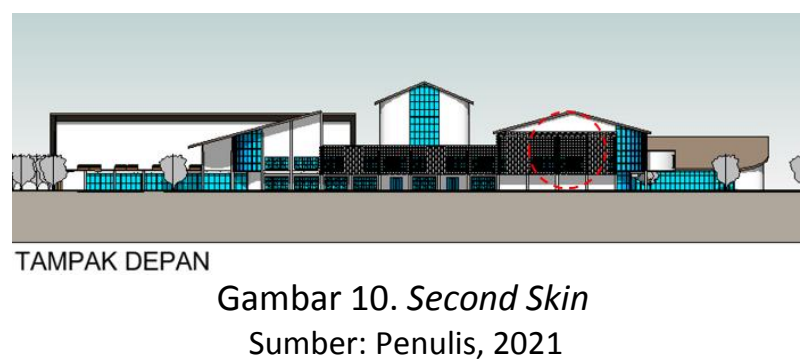

- Courtyard

Merupakan area multifungsi yang terbuka untuk umum yang menyatukan dua fungsi utama fasilitas yaitu penjernihan air dan riset.

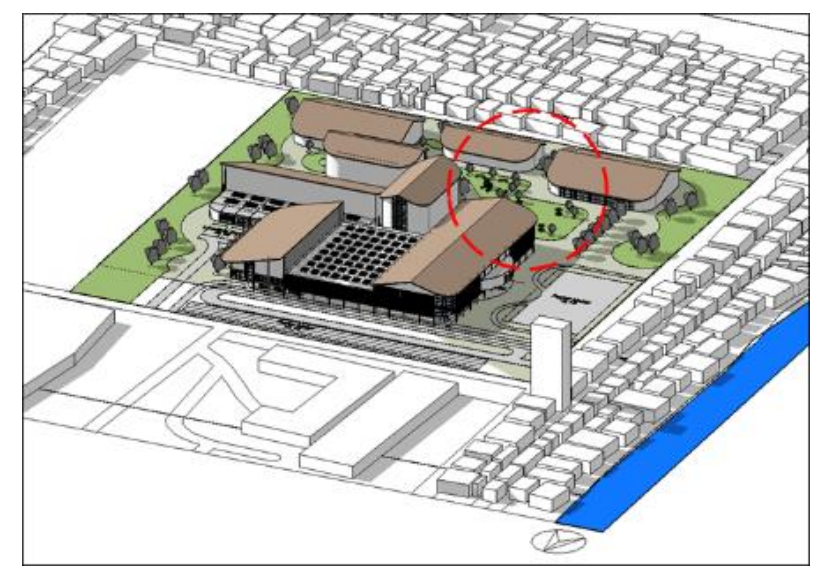

Gambar 11. Courtyard

Sumber: Penulis, 2021

\section{Tampilan Desain Akhir}

Proyek Perancangan terdiri atas beberapa bentukan massa. Dapat dilihat ada tiga massa yang merepresentasikan tiga fungsi utama dalam proyek perancangan tsb: (1) fungsi penjernihan air, (2) fungsi riset dan pengamatan, dan (3) fungsi pengemasan dan penjualan air bersih dan bahan makanan. Hal ini mengikuti konsep perancangan mengikuti proses / alur aktivitas.

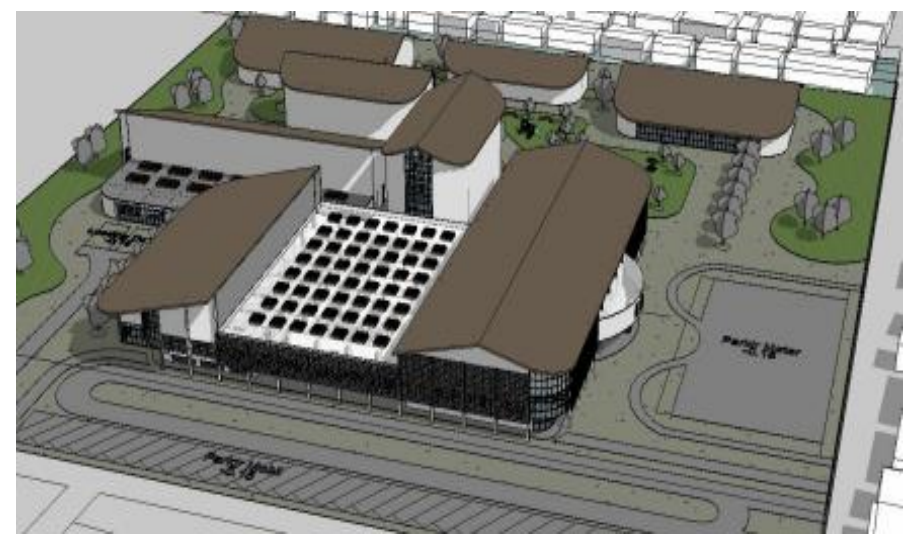

Gambar 12. Bentukan Massa Proyek Perancangan

Sumber: Penulis, 2021 


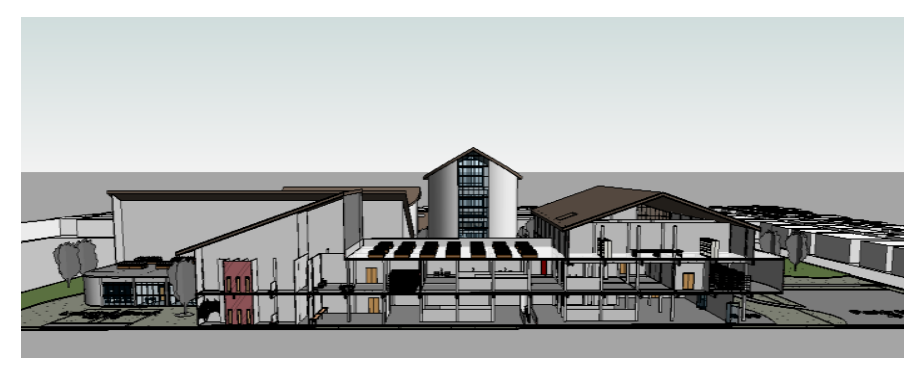

Gambar 13. Potongan 3D

Sumber: Penulis, 2021

\section{KESIMPULAN}

Fasilitas Pemenuhan Kebutuhan Air Bersih Masyarakat Penjaringan adalah Proyek Perancangan yang memiliki tujuan untuk meningkatkan kualitas dan kuantitas air bersih di Kelurahan Penjaringan agar masyarakat yang bertempat tinggal atau bekerja di area tersebut dapat memenuhi kebutuhan air bersih sehari-hari mereka karena ada sumber air bersih yang handal.

Waduk Pluit merupakan sumber air alternatif yang memiliki potensi besar untuk memenuhi kebutuhan air bersih masyarakat setelah melalui proses penjernihan. Fungsi utama proyek perancangan yaitu proses penjernihan air Waduk Pluit tersebut. Selain fungsi penjernihan / purification, ada fungsi riset dan pengamatan untuk memonitor dan mengembangkan kualitas air bersih yang diproses, akuaponik yang selain merupakan sarana penunjang penelitian air bersih juga dapat memproduksi bahan makanan, dan fungsi edukasi untuk memberikan pengenalan dan penjelasan kepada masyarakat tentang sistem penjernihan air, pengoperasian, dan perawatannya baik untuk yang sederhana untuk skala kecil (rumah tangga) maupun untuk skala sedang. Air bersih yang dihasilkan kemudian dapat diperoleh masyarakat setempat melalui jasa antar maupun toko.

Konsep proyek perancangan kontekstual dan keseharian dimana desain menggunakan material dan bentuk atap sesuai bentuk atap dan material atap bangunan-bangunan di sekitarnya dan terdapat area-area komunal multi fungsi dimana pengunjung dapat berkumpul bersama. Konsep bentukan massa berdasarkan alur aktivitas di dalam bangunannya dan fungsi dari penjernihan air kotor sampai ke area penjualan air bersih. 


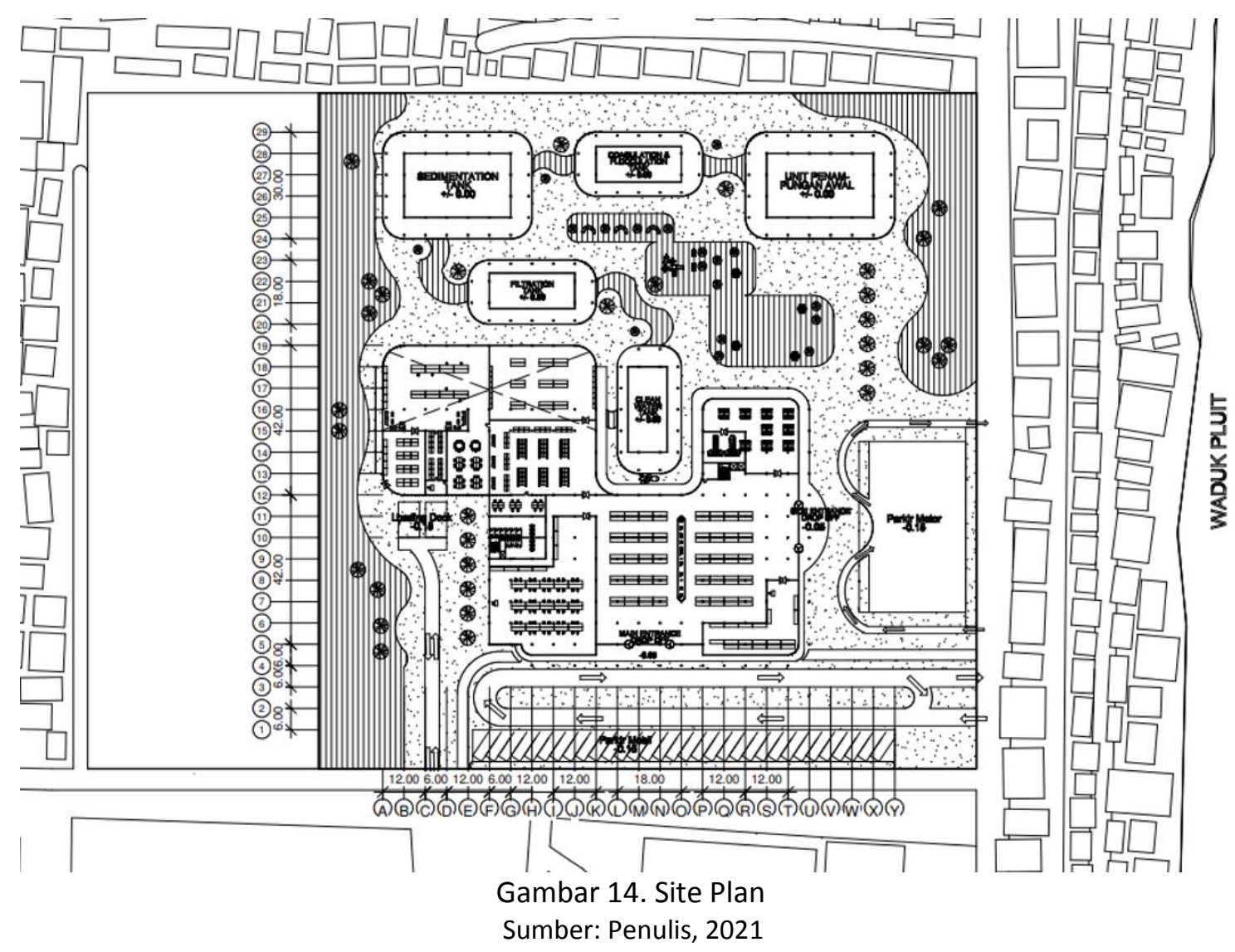

\section{REFERENSI}

Afrina, P. (2019) (n.d). Air Baku. Diunduh pada tanggal 5 Mei 2019 https://www.academia.edu/8039594/AIR_BAKU diakses tanggal 12 Agustus 2021

Bps.go.id diakses pada tanggal 13 April 2021

Daniel, W. (2008). Building Type Basic for Research Laboratories. NY: John Willey \& Sons Inc. New York

Keputusan Menteri Kesehatan Republik Indonesia NOMOR 907/MENKES/SK/VII/2002, "Tentang syarat-syarat dan pengawasan kualitas air minum", 2002.

Linsley, R, K. \& Franzini, JB., (1989). Teknik Sumber Daya Air. Jakarta : Erlangga.

Meidhitasari, (2007). Evaluasi dan Modifikasi Instalasi Pengolahan Air Minum Miniplan Dago Pakar, Tugas akhir S1, Prodi Teknik Lingklungan, ITB

Research Journal of Engineering Science, Vol. 2 No. 6, hlm. 45-51.

Sastro. (2016). Teknologi Akuaponik Mendukung Pengembangan Urban Farming. Jakarta:Balai Pengkajian Teknologi Pertanian (BPTP) Jakarta

Sutrisno, C Totok, (2000). Teknologi Penyediaan Air Bersih. Jakarta : Rineka Cipta.

Suyono, (1993). Pengelolaan Sumber Daya Air. Fakultas Geografi Universitas Gadjah Mada. Yogyakarta.

Seshagiri R., M. V.; Reddy, V. S.; Hafsa, P. M.; Veena, P.; \& Ausha, P., (2013), "Bioengineered Concrete - A Sustainable Self-healing Construction Material", 